International Journal on Integrating Technology in Education (IJITE) Vol.5, No.2, June 2016

\title{
E-LEARNING READINESS ASSESSMENT TOOL For PhilipPine Higher EduCATION INSTITUTIONS
}

\author{
Jo Ann D. Doculan \\ College of Computer Science, Ifugao State University,Nayon, \\ Lamut, Ifugao, Philippines
}

\begin{abstract}
The growth of internet technologies changed learning strategies globally. The Philippines is no exemption. Due to its usefulness and potential, E-learning is becoming popular. But before these benefits would be enjoyed, it is very important for an institution to be assessed. This is to identify the needs and factors that directly affect their readiness. This study presents a readiness assessment tool for Philippine Higher Education Institutions. It also serves as a needs assessment instrument.
\end{abstract}

\section{KEYWORDS}

E-learning, E-learning Readiness, assessment tool

\section{INTRODUCTION}

The evolution of technology addresses the gaps in teaching and learning. E-learning (EL) is the use of technology to enhance teaching and learning activities. Oye et.al said that it is a used to describe the fields of online learning, web-based training and technology delivered instructions [1]. The main purpose of E-Learning is to increase accessibility of education and reducing costs. It also increases productivity [2] while enhancing independent learning ([3]. This approach of learning facilitates students at different continents to attend the same classes almost at the same time [4]. It also creates economic benefits, and make lifelong learning opportunity for all [5]. Cai [6] further concludes that e-learning brings changes in pedagogical strategies and improves the efficiency of teaching and learning. This was agreed by Akhondi [7].Educational institutions strive to meet the needs of all stake holders due to the advances in web-based learning [8].

Higher Education Institutions in the Philippines were mandated to change the curriculum to Outcomes-Based Education. In 2012,the Commission on Higher Education (CHED) thru its CHED Memorandum Order No. 46, ordered the promotion and adoption of learner-centred learning. This is the essence of e-learning. This initiative is promising but issues arise on the readiness of state universities and colleges in adopting such change. The use of technology in the country is still in its infancy, shifting to e-learning platform is still on its planning stages.

The benefits of eLearning can only be experienced if the organization is deemed prepared. Learning institutions should first assess their readiness to integrate e-learning. This is if they want to implement and benefit from it [9].

Borotis and Poulymenakou [10] defined e-learning readiness (ELR) as the mental or physical preparedness of an organization.ELR assessment helps an organization to design e-learning strategies comprehensively. Learners and teachers must also be e-ready so that an achievable strategy may be implemented. ELR assessment provides key information to organizations who are willing to supply e-learning solutions. These solutions cater for the specific needs of each 
International Journal on Integrating Technology in Education (IJITE) Vol.5, No.2, June 2016

learning [11].It is for these reasons that universities should evaluate their readiness, define their requirements and identify their degree of e-readiness through objective assessment [12].

There are several models proposed in assessing the degree of e-learning readiness. The most popular are those of Watkins [13], Chapnick [14], Aydin \& Tasci [15], Borotis \& Poulymenakou [10], Rosenberg [16], Broadbent [17], Anderson [18], Mercado [19], Kaur \& Abas [20], and Psycharis [21].

These models have been implemented in e-matured institutions and not in developing countries like the Philippines. Rogers stressed that every system has its own norms that can be effective in diffusing an innovation in its system [22]. To ensure that actual benefit of e-learning is valid in appropriate situations, there is a need to measure the readiness of an organization or individual, appropriately. Further, e-learning models may not be appropriate to use across countries due to the varying needs of the role-players.

The succeeding sections discusses the method used along with the discussion of the results. In the Method section, it discusses the procedures done in developing and validating the tool. The instrument subsection discusses the tool itself while the respondents subsection discusses the participants in the data collection. The Results and Discussion section presents the results and discussion of the data collection and analysis. Lastly, conclusions and recommendations are presented.

\section{METHOD}

Literature review was conducted which served as the basis for the formulation of e-learning dimensions suited for Philippine setting. There were twenty two literatures considered for analysis and served as the basis for this study.

\subsection{Instrumentation}

The core of the questionnaire was is set of items relating to issues that have been proposed in the literature to assess the readiness towards e-learning. Moreover, it assesses the factors that influence the success of e-learning initiatives. The items are close-ended and developed specifically for this study. These are divided into three sets of factors reflecting the structural division of roles in higher education institutions. These are institutional, teacher, and student factors. Each role has a different questionnaire.

The instrument for the teacher describes the profile of the teacher. Also, it measures access to technology, confidence, attitudes, training and their perceived usefulness. The second instrument describes the demographic profile of the student, measures access to technology and confidence. It also measure attitudes, training, social support and perceived usefulness. Finally, the third instrument measures institutional readiness. It measures ICT infrastructure, administrative and resource support. The questionnaire is patterned from Mercado's [19] tool. It is further incorporated with factors discussed in the literature which are deemed of importance.

\subsection{Respondents}

To verify the reliability of the instrument, data were taken from 28 faculty members of the College of Computer Science, 83 students and 5 administrative officers of the Ifugao State University, main campus. 


\section{RESULTS AND DISCUSSION}

The Cronbach's alpha was determined to verify the reliability of the instrument. Results show that each dimension has a Cronbach's Alpha of 6 and above. This means thatthe instrument is reliable. Some items in the questionnaire were not included to increase its Cronbach's Alpha. This resulted to the compression of the instrument. The participants in the survey were composed of 28 faculty, 83 students and 5 administrators.

Table 1 indicates the Cronbach's Alpha coefficient for each sub-dimension in the Student instrument wherein 9 items were deleted to increase its reliability. The student questionnaire was reduced from 72 to 63 items.

Table 1. Cronbach's Alpha coefficient in the Student instrument

\begin{tabular}{|l|l|l|l|l|}
\hline Categories & $\begin{array}{l}\text { No. of } \\
\text { Items }\end{array}$ & Cronbach's Alpha & Item deleted & $\begin{array}{l}\text { Cronbach's Alpha } \\
\text { if item deleted }\end{array}$ \\
\hline Technology Access & 9 & .991 & Q9 & .828 \\
\hline Tech. Confidence & 14 & .733 & Q25 and Q27 & .737 \\
\hline Training & 6 & .719 & Q28 & .749 \\
\hline Social Support & 6 & .633 & Q37 & .714 \\
\hline Study Habits & 9 & .874 & Q46 & .888 \\
\hline Abilities & 5 & .740 & & \\
\hline Motivation & 8 & .898 & Q56 & .978 \\
\hline Time Management & 6 & .611 & Q66 & .668 \\
\hline Perceived Usefulness & 5 & .951 & Q67 & .953 \\
\hline
\end{tabular}

It can be gleaned in Table 2 that 3 items were deleted to increase its Cronbach's Alpha. This led to the reduction of the teacher instrument from 78 to 75 questions.

Table 2. Cronbach's Alpha coefficient in the Teacher's instrument.

\begin{tabular}{|l|l|l|l|l|}
\hline Categories & $\begin{array}{l}\text { No. } \\
\text { of } \\
\text { items }\end{array}$ & $\begin{array}{l}\text { Cronbach's } \\
\text { Alpha }\end{array}$ & $\begin{array}{l}\text { Item } \\
\text { deleted }\end{array}$ & $\begin{array}{l}\text { Cronbach's Alpha if } \\
\text { item deleted }\end{array}$ \\
\hline Technology Access & 9 & .695 & Q1 & .706 \\
\hline Technological Confidence & 18 & .927 & Q10 & .941 \\
\hline Training & 6 & .992 & Q28 & .994 \\
\hline Teaching Styles and Strategies & 15 & .998 & & \\
\hline Abilities & 14 & .999 & & \\
\hline Motivation & 6 & 1.0 & & \\
\hline Time Management & 4 & 1.0 & & \\
\hline Perceived Usefulness & 5 & 1.0 & & \\
\hline
\end{tabular}

Table 3 shows that three items in the institution instrument were deleted to increase its Cronbach's Alpha. This resulted to the reduction of the instrument from 27 to 24 questions. 
International Journal on Integrating Technology in Education (IJITE) Vol.5, No.2, June 2016

Table 3. Cronbach's Alpha coefficient in the Institution instrument.

\begin{tabular}{|l|l|l|l|l|}
\hline Categories & $\begin{array}{l}\text { No. of } \\
\text { Items }\end{array}$ & $\begin{array}{l}\text { Cronbach's } \\
\text { Alpha }\end{array}$ & $\begin{array}{l}\text { Item } \\
\text { deleted }\end{array}$ & $\begin{array}{l}\text { Cronbach's Alpha if } \\
\text { item deleted }\end{array}$ \\
\hline ICT Infrastructure & 14 & .801 & Q13 & .828 \\
\hline $\begin{array}{l}\text { Administrative Support (policies and } \\
\text { commitment) }\end{array}$ & 5 & .765 & Q1 & .816 \\
\hline Human, Financial and Tech. Support & 8 & .914 & Q21 & .920 \\
\hline
\end{tabular}

Though the instrument is found to be reliable, respondents especially students, find the questionnaire tedious to answer. It took them 45 minutes to answer and resulted to the wastage of 31 questionnaires. These were not completely-filled up and thus, not included. The resulting questionnaire is presented in the succeeding tables.

\subsection{The Student Questionnaire}

Tables 4,5 , and 6 present the three sections of the student questionnaire along technology access, Technological confidence, support and training, and, Attitudes towards a successful online learner. The section Technology Access is answerable with Yes or No.

Table 4.Technology Access

\begin{tabular}{|c|c|}
\hline \multirow{8}{*}{  } & 1. I own a computer(pc, laptop) / smartphone \\
\hline & 2. I have access to a dependable computer (in school, cafes) \\
\hline & 3. I have access to a computer with the necessary software installed \\
\hline & 4. I have access to a computer with a printer installed \\
\hline & 5. I have access to a computer and internet connection at home \\
\hline & 6. I have access to a computer in campus or internet cafes with internet connection \\
\hline & $\begin{array}{l}\text { 7. I have access to a computer installed with search engines( ex. Google, Ask) and } \\
\text { internet browsers( ex. IE, Firefox, Google Chrome) }\end{array}$ \\
\hline & 8. I have a virus protection on my computer \\
\hline
\end{tabular}

Table 5 is focused on measuring technological confidence, support and training. It is a 5-point Likert Scale response where 1= Not at all, 2=Very least extent, 3= little extent, 4= Great extent, $5=$ very great extent with each statement.

Table 5. Technological Confidence, Support and Training

\begin{tabular}{|c|c|}
\hline \multirow{4}{*}{ 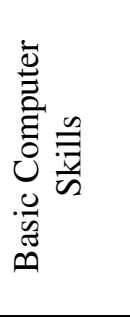 } & $\begin{array}{l}\text { 9. I know the basic functions of computer hardware components ( CPU and } \\
\text { monitor) including its peripherals like the printer, speaker and mouse. }\end{array}$ \\
\hline & 10. I know how to save/open documents to/from \\
\hline & $\begin{array}{l}\text { 11.I am comfortable with things like installing software and changing } \\
\text { configuration settings on my computer. }\end{array}$ \\
\hline & $\begin{array}{l}\text { 12. I know how to resolve common hardware or software problems or I can } \\
\text { access a technical support in case I encounter a problem }\end{array}$ \\
\hline \multirow{4}{*}{ 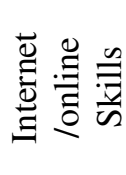 } & 13. I can send an email with file attachments \\
\hline & 14. I am familiar with online etiquette \\
\hline & 15. I know how to surf the internet and navigate the web \\
\hline & 16. I can use web browsers(eg. Internet Explorer, Google Chrome) confidently \\
\hline
\end{tabular}


International Journal on Integrating Technology in Education (IJITE) Vol.5, No.2, June 2016

\begin{tabular}{|c|c|}
\hline & $\begin{array}{l}\text { 17. I know how to resolve common errors while surfing the internet like "page } \\
\text { cannot be found" or "connection time out" }\end{array}$ \\
\hline & $\begin{array}{l}\text { 18. I am comfortable with things like doing searches, setting bookmarks, and } \\
\text { downloading files }\end{array}$ \\
\hline & 19. I know how to access an online library and other resource database \\
\hline & $\begin{array}{l}\text { 20. I know how to use asynchronous tools (eg. Discussion boards, chat tools) } \\
\text { effectively }\end{array}$ \\
\hline & 21. I know what PDF files are and I can download and view them \\
\hline$\stackrel{\circlearrowright}{\Xi} \cong$ & 22. I am comfortable with word processing and use it comfortably \\
\hline$\sum_{0}^{3} \cdot \overline{0} \frac{\bar{n}}{2}$ & $\begin{array}{l}\text { 23. I am able to have several applications opened at the same time and move } \\
\text { between them }\end{array}$ \\
\hline & 24. I know how to use spreadsheet application \\
\hline & 25. I have prior training on e-learning \\
\hline & 26. I have attended online classes \\
\hline$\Xi$ & 27. I have used a learning management system before \\
\hline 雹 & $\begin{array}{l}\text { 28. I have the skills to modify and add content and assessment using an online } \\
\text { learning management system }\end{array}$ \\
\hline & 29. I have attended seminars/workshops related to online learning activities \\
\hline & 30. My parents encourage me to use the internet for learning purposes \\
\hline 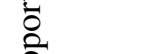 & 31. My parents encourage me to use electronic devices for learning purposes \\
\hline$\stackrel{\vec{Z}}{\mathscr{2}}$ & 32. My teachers encourage me to use the internet for learning purposes \\
\hline$\frac{\pi}{8}$ & $\begin{array}{l}\text { 33. My friends encourage me to learn with the use of the internet and electronic } \\
\text { materials }\end{array}$ \\
\hline & 34. The school provides us e-learning materials and opportunity to learn online \\
\hline
\end{tabular}

Table 6 measures attitudes towards a successful online learner. It is a 4-point Likert scale response where $1=$ Never, $2=$ Sometimes, $3=$ Often, $4=$ Very often.

Table 6. Attitudes towards a successful online learner

\begin{tabular}{|c|c|}
\hline \multirow{8}{*}{ 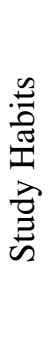 } & 35. When I have an important assignment \\
\hline & 36. I prefer to study or work alone \\
\hline & 37. I look forward to learning new skills and master them quickly \\
\hline & 38. As a learner, I am highly confident \\
\hline & 39. I am able to refrain from distractions and stay on task while studying \\
\hline & 40. When asked to learn new technologies, I do not put it off \\
\hline & 41. I am determined to stick to studies despite challenging situations \\
\hline & 42. I don't need direct lecture to understand learning materials \\
\hline \multirow{5}{*}{ 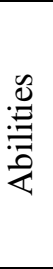 } & 43. I am able to express my thoughts and ideas in writing \\
\hline & 44. I am a self-starter \\
\hline & 45. I am able to communicate effectively with others using online technologies \\
\hline & 46. I take responsibility for my own learning \\
\hline & $\begin{array}{l}\text { 47. Taking responsibility for staying in contact with my instructor would be } \\
\text { easy for me }\end{array}$ \\
\hline \multirow{3}{*}{ 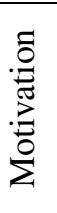 } & $\begin{array}{l}\text { 48. I consider flexibility in time as an important motivating factor in taking an } \\
\text { online class }\end{array}$ \\
\hline & 49. I am highly motivated and enthusiastic to take an online course \\
\hline & $\begin{array}{l}\text { 50. I enjoy learning that is both interesting and challenging and I am motivated } \\
\text { in such situations to go beyond the minimum requirements }\end{array}$ \\
\hline
\end{tabular}


International Journal on Integrating Technology in Education (IJITE) Vol.5, No.2, June 2016

\begin{tabular}{|c|c|}
\hline & $\begin{array}{l}\text { 51. I would be able to remain motivated even though the instructor is not online } \\
\text { at all times }\end{array}$ \\
\hline & 52. I set a goal before starting a task \\
\hline & $\begin{array}{l}\text { 53. I would be able complete my work even when there are online distractions } \\
\text { (eg. Friends sending emails, websites to search) }\end{array}$ \\
\hline & $\begin{array}{l}\text { 54. I would be able to complete my work even when there are in my home (eg. } \\
\text { Television, children and such). }\end{array}$ \\
\hline & $\begin{array}{l}\text { 55. Considering my schedule, I am able to spend significant time and energy to } \\
\text { engage in online learning class }\end{array}$ \\
\hline$\underset{0}{0}$ & 56. I do not have trouble getting things done on time \\
\hline$\stackrel{\mathscr{\Xi}}{\Xi}$ & 57. I am able to organize my time well so that work and tasks don't build up \\
\hline$\dot{E} \bar{\Sigma}+$ & 58. I can sacrifice personal time to complete assignments and readings \\
\hline & 59. Learning would be more effective with the use of online learning materials \\
\hline & 60. E-learning would improve my learning process \\
\hline & 61. Learning online reduces the time I spend on unproductive activities \\
\hline$\stackrel{\mathscr{\omega}}{\mathscr{E}}$ & $\begin{array}{l}\text { 62. Learning online saves me money I spend on printed learning materials and } \\
\text { transportation cost }\end{array}$ \\
\hline  & $\begin{array}{l}\text { 63. Online collaboration improves my written communication and analytical } \\
\text { thinking skills. }\end{array}$ \\
\hline
\end{tabular}

\subsection{The Teacher Questionnaire}

It is presented in tables 7,8 and 9 , the three sections of the teacher instrument which measures Technology access, Technological confidence and Training, and Attitudes toward a successful online teacher. Table 7 measures technology access and is answerable with Yes or No.

Table 7. Technology Access

\begin{tabular}{|c|c|}
\hline \multirow{7}{*}{  } & 1. I have access to a dependable computer (in school, cafes) \\
\hline & 2. I have access to a computer with the necessary software installed \\
\hline & 3. I have access to a computer with a printer installed \\
\hline & 4. I have access to a computer and internet connection at home \\
\hline & 5. I have access to a computer with internet connection \\
\hline & $\begin{array}{l}\text { 6. I have access to a computer installed with search engines (ex. Google, Ask) } \\
\text { and internet browsers (ex. IE, Firefox, Google, Chrome) }\end{array}$ \\
\hline & 7. I have a virus protection on my computer \\
\hline
\end{tabular}

Table 8 presents questions to measure technological confidence and training. It is a 5-point Likert Scale response where $1=$ Not at all, $2=$ Very least extent, $3=$ Little extent, $4=$ Great extent, $5=$ very great extent with each statement. 
International Journal on Integrating Technology in Education (IJITE) Vol.5, No.2, June 2016

Table 8. Technological confidence and Training

\begin{tabular}{|c|c|}
\hline \multirow{3}{*}{ 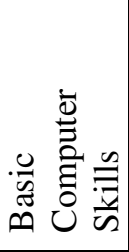 } & $\begin{array}{l}\text { 8. I know how to save/open documents to/from a hard disk or other removable } \\
\text { storage device. }\end{array}$ \\
\hline & $\begin{array}{l}\text { 9. I am comfortable with things like installing software and changing } \\
\text { configuration settings on my computer. }\end{array}$ \\
\hline & $\begin{array}{l}\text { 10. I know how to resolve common hard ware or software problems or I can access } \\
\text { a technical support in case I encounter a problem. }\end{array}$ \\
\hline \multirow{8}{*}{ 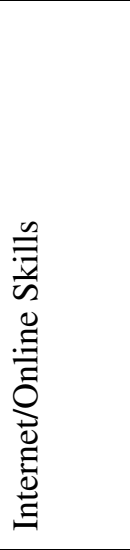 } & 11. I have an email address and I can open//send with file attachments. \\
\hline & 12. I am familiar with online etiquette. \\
\hline & $\begin{array}{l}\text { 13. I now I know how to surf the internet and navigate the web pages (go to next, or } \\
\text { previous page). }\end{array}$ \\
\hline & $\begin{array}{l}\text { 14. I can use web browsers ( e.g. Internet Explorer, Google Chrome, Mozilla } \\
\text { Firefox) confidently }\end{array}$ \\
\hline & $\begin{array}{l}\text { 15. I know how to resolve common errors while surfing the internet such as "page } \\
\text { not found" or "connection timed out" }\end{array}$ \\
\hline & $\begin{array}{l}\text { 16. I am comfortable with things like doing searches, setting,bookmarks, and } \\
\text { downloading files. }\end{array}$ \\
\hline & 17. I know how to access an online library and other resource database. \\
\hline & $\begin{array}{l}\text { 18. I know how to use asynchronous tools (e.g. discussion, boards, chat tools) } \\
\text { effectively; }\end{array}$ \\
\hline \multirow{6}{*}{ 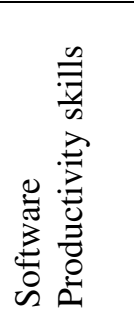 } & 19. I know what PDF files are and I can download and view them. \\
\hline & 20. I am familiar with word and use it comfortably. \\
\hline & $\begin{array}{l}\text { 21. I am able to have several applications opened at the same time and move } \\
\text { between them. }\end{array}$ \\
\hline & 22. I know how to use file compression (winzip, rar, etc.) \\
\hline & 23. I know how to use spreadsheet application ( MS-Excel). \\
\hline & 24. I know how to use presentation software. \\
\hline \multirow{5}{*}{ 恶 } & 25. I have training on the use of the internet. \\
\hline & 26. I have attended online classes before. \\
\hline & 27. I have used a learning management system before \\
\hline & $\begin{array}{l}\text { 28. I have the skills to modify and add content and assessment using an online } \\
\text { learning management system. }\end{array}$ \\
\hline & 29. I have attended seminars/ workshops related to online learning activities. \\
\hline
\end{tabular}

Table 9 measures attitudes towards a successful online learner. It is a 4-point Likert scale response where $1=$ Never, $2=$ Sometimes, $3=$ Often, $4=$ Very often.

Table 9. Attitudes towards a successful online teaching

\begin{tabular}{|c|c|}
\hline \multirow{7}{*}{ 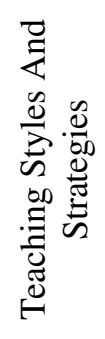 } & 30. I use discussion as a teaching strategy for the subjects that I teach. \\
\hline & 31. I encourage independence and creativity from my student \\
\hline & 32. I facilitate and monitor appropriate interaction among students; \\
\hline & 33. As a teacher, I support student-centered learning \\
\hline & 34. I am flexible in dealing with student's needs (due dates, absences, make-up exams) \\
\hline & 35. Critical thinking and problem solving are important skills for my students. \\
\hline & $\begin{array}{l}\text { 36. I use strategies to encourage active learning, interaction, participation, and } \\
\text { collaboration among students. }\end{array}$ \\
\hline
\end{tabular}




\begin{tabular}{|c|c|}
\hline & $\begin{array}{l}\text { 37. I use effective strategies and techniques that actively engage students in the } \\
\text { learning process ( e.g. use effective strategies and techniques that actively engage } \\
\text { students in the learning process (e.g. team problem-solving, in-class writing, } \\
\text { analysis, synthesis and evaluation instead of passive lectures). }\end{array}$ \\
\hline & 38. I encourage learning through group interaction. \\
\hline & $\begin{array}{l}\text { 39. I provide timely, constructive feedback to students about assignments and } \\
\text { questions. }\end{array}$ \\
\hline & $\begin{array}{l}\text { 40. I use appropriate strategies designed to accommodate the varied talents and skills } \\
\text { of my students. }\end{array}$ \\
\hline & $\begin{array}{l}\text { 41. I provide student-centered lessons and activities that are based on concepts of } \\
\text { active learning and that are connected to real-world applications. }\end{array}$ \\
\hline & 42. My teaching goals and methods address a variety of student learning styles. \\
\hline & 43. As a teacher, I view myself as a facilitator. \\
\hline & 44. I immediately consult with students to correct problems and keep them on task. \\
\hline & 45. I use the internet to locate resources for teaching. \\
\hline & 46. I work well with students with different cultural background. \\
\hline & 47. I communicate with students very well. \\
\hline & 48. I have very good reading comprehension skills. \\
\hline & 49. I am able to condense multiple perspectives into a coherent discussion. \\
\hline & $\begin{array}{l}\text { 50. I can work independently, without the traditional class arrangement (students \& } \\
\text { teacher in the same class at the same time) }\end{array}$ \\
\hline$\stackrel{\mathscr{\varrho}}{:}$ & $\begin{array}{l}\text { 51. I can often complete difficult tasks on my own, even if others do not provide } \\
\text { support and encouragement }\end{array}$ \\
\hline$\vec{z}$ & 52. I feel I will be able to comfortable work online \\
\hline & 53. I am able to comfortable communicate almost entirely through writing \\
\hline & $\begin{array}{l}\text { 54. I am able to establish effective environment for student-teacher and student- } \\
\text { student interaction }\end{array}$ \\
\hline & 55. I am capable of self-discipline \\
\hline & 56. I able to work in a non-structured environment \\
\hline & 57. I assume responsibility for preparation and presentation of learning tasks \\
\hline & 58. I have the ability to experiment with new pedagogical approach \\
\hline & $\begin{array}{l}\text { 59. My interest in online teaching is motivated by the flexibility it will give me to } \\
\text { decide when I do my work }\end{array}$ \\
\hline & $\begin{array}{l}\text { 60. My interest to teach online is motivated by the opportunity for me to pursue } \\
\text { personal interests that are not work-related }\end{array}$ \\
\hline 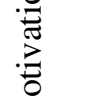 & $\begin{array}{l}\text { 61. My interest to teach online is motivated by the opportunity to have more free time } \\
\text { for other professional activities (attending conferences, consulting, etc.) }\end{array}$ \\
\hline$\sum^{0}$ & 62. Having a more convenient way to teach highly motivates me to teach online \\
\hline & 63. I am committed to teaching \\
\hline & 64. I am highly motivated and enthusiastic \\
\hline & 65. I set a goal before starting a task \\
\hline & $\begin{array}{l}\text { 66. I can dedicate } 4 \text { to } 6 \text { hours a week (anytime during the day or night) to participate } \\
\text { in the online class }\end{array}$ \\
\hline$\underset{\overparen{E}}{\mathscr{E}}$ & $\begin{array}{l}\text { 67. I am willing to log on and contribute to an online classroom discussion and } \\
\text { interact with student }\end{array}$ \\
\hline 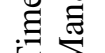 & 68. I am willing to devote more time to an online class than an onsite class \\
\hline & 69. I am able to create schedules for myself and stick to them \\
\hline & 70. Teaching is more effective and fun with the use of online learning materials \\
\hline 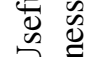 & 71. E-learning improves the learning process and experience of students \\
\hline & 72. Teaching with e-learning improves my teaching methodology \\
\hline
\end{tabular}


73. Online collaboration motivates students to actively participate in any discussion

74. Using online resources increases my productivity

\subsection{The Institutional questionnaire}

Tables 10, 11, and 12 present the dimensions of the questionnaire for administrators along ICT infrastructure, Administrative support, and Resource support. Table 10 presents questions on ICT infrastructure readiness which are answerable with Yes or No.

Table 10. ICT Infrastructure for a Successful E-Learning Implementation

1. There is sufficient ICT hardware for e-learning use

2. There is a stable internet connection in the university

3. There is a steady supply of electricity in the campus

4. There is a an existing contingency plan in case of breakdown

Tables 11 and 12 measure Administrative support along commitment and policies and resource support along human, financial and technical aspects. It is a 4-point Likert scale where $\mathbf{1}=$ Probably not, 2=Maybe, $\mathbf{3}=$ Quite likely $\mathbf{4}=$ Definitely.

Table 11. Administrative Support (Commitment and Policies)

5. An e-learning is aligned with the institution's VGMO

6. There is a commitment on the part of institutional leaders to use technology to achieve strategic academic goals.

7. There is commitment on the part of institutional leaders to use technology to achieve strategic goals and that such commitment extends beyond just using technology.

8. The institution is willing to employ or assign an academically capable and/or experienced faculty to oversee the implementation of the e-learning environment.

9. The institution is willing to accept e-learning as a mode for teaching and learning.

10. The institution support employees who seek out non-traditional development programs or experiences.

12. The institution ensures to put up a committee that will work directly with the development of online courses and programs.

13. The institution provides teachers with professional development opportunities to assist them in improving their online teaching.

14. The institution support teachers to have access to a network of other online practitioners to discuss pedagogical and curricular issues.

15. The institution is willing to provide a professional support system is in place to ensure teacher success in delivering the online course.

16. The institution is willing to make provisions The institution is willing to make provisions for collaborative teaching arrangement

17. The institution is committed to learner-centered instruction.

18. Computing is firmly integrated into institution's culture.

Table 12. Resource Support (Financial, Human, Technical)

19. The institution is financially ready to venture into e-learning

20. The institution has experienced human resources, or a department that organizes trainings related to online learning 
International Journal on Integrating Technology in Education (IJITE) Vol.5, No.2, June 2016

\begin{tabular}{|c|c|}
\hline 22. & $\begin{array}{l}\text { Adequate and timely support is available to the teacher and students when technical issues } \\
\text { arise. }\end{array}$ \\
\hline 23. & $\begin{array}{l}\text { The institute has a courseware delivery system (LMS ) through which courses and programs } \\
\text { are delivered }\end{array}$ \\
\hline 24. & $\begin{array}{l}\text { The online platform used for course delivery has the necessary system capacity to support } \\
\text { the learning activities of the course }\end{array}$ \\
\hline
\end{tabular}

\section{CONCLUSIONS}

Results show that the instrument is reliable with each dimension in every role having a Cronbach's Alpha of 6 and above. The non-inclusion of some items in the questionnaire increases its Cronbach's Alpha which led to the compression of the instrument. It is therefore concluded that the tool is reliable and suited for Philippine Setting.

However, the students find the questionnaire time-consuming.

\section{RECOMMENDATIONS}

While the instrument yielded positive reliability, it is recommended that it would still be reduced to shorten the time spent in answering. This way, students especially, would concentrate answering and completely fill-up the questionnaire.

It is recommended further that factor analysis would be conducted to compact the tool. Finally, this tool is recommended for Philippine Higher Education Institutions which are considering to implement e-learning platforms, especially the state universities and colleges.

\section{REFERENCES}

[1] Oye , N. D., Salleh, M., \& Iahad, N. A. (2010).” Holistic E-learning in Nigerian Higher Education Institutions". Journal of Computing, 2(11), 20-26

[2] Chen, K. C.\&Jang, S. J. (2010). "Motivation in online learning: Testing a model of self-determination theory". Computers in Human Behaviour, 26, 741-752.

[3] Chen, H. \& Kao,C. (2012). "Empirical validation of the importance of employees' learning motivation for workplace e-learning in Taiwanese organisations". Australasian Journal ofEducational Technology, 28(4), 580-598.

[4] Nagarajan, P. \& Wiselin, J., (2010). Online Educational System (e- learning) International Journal of u- and e- Service, Science and Technology, Vol. 3, No. 4.

[5] Mohamadzadeh, M., Farzaneh, J., Mousavi, M., \&Maghabl, R, (2012)"Challenges and Strategies for E-Learning Development in the University of Payam Noor in Iran”.Turkish Online Journal of Distance Education, v13 n4 p297-308

[6] Cai, H. (2012) "E-learning and English teaching". IERI Procedia, 2, 841 - 846. Elsevier B.V. DOI: 10.1016/j.ieri.2012.06.180.

[7] Akhondi, A. (2011). "Taking advantage of virtual learning in improving the teaching process learning from the perspective of university professors in Iran at year 2011".Procedia - Social and Behavioral Sciences, 28, 448 - 450, Elsevier Ltd

[8] Lion, R. \& Stark, G. (2010), "A Glance at Institutional Support for Faculty Teaching in an Online Learning Environment”. Educause Quarterly ISSN 1528-5324 Volume 33, Issue 3.

[9] Saekow, A. \& Samson, D.(2011)“E-learning Readiness of Thailand's Universities Comparing to the USA's Cases.'.International Journal of e-Education, e-Business, e-Management and e-Learning, Vol. 1 , No. 2 
International Journal on Integrating Technology in Education (IJITE) Vol.5, No.2, June 2016

[10] Borotis, S. \&Poulymenakou, A. (2008). Critical Success Factors for E-Learning Adoption: Handbook of Research on Instructional Systems and Technology. Greece: IGI Global.

[11] Mcconnell, D. (2008). "Examining Conceptions of E-learning in an Intercultural Sino-UK Context". Paper presented at the Proceedings of the 6th International Conference on Networked Learning, Halkidiki-Greece.

[12] AbuSneineh, W. \& Zairi, M. (2010). “An Evaluation Framework for E-Learning Effectiveness in the Arab World”. International Encyclopaedia of Education, pp. 521-535.

[13] Watkins, R., Leigh, D. \&Triner, D. (2004). Assessing Readiness for E-learning. Performance Improvement Quality. 17(4), 66-79.

[14] Chapnick, S. (2000). “Are you ready for elearning?” American Society for Training \& Development. $\mathrm{URL}=\quad$ www.gc21.de/ibt/en/site/gc21/

ibt/permanent/ publicforum/dok/are_you_ready_for_elearning.pdf

[15] Aydin, C.H. \& Tasci, D. (2005). "Measuring readiness for e-learning: reflections from anemerging country”. Educational Technology \& Society, 8 (4), 244-257.

[16] Broadbent, B. (2001). Tips to help decide if your organizationis ready for e-learning. URL=http://icde.net/en/ arshive/articles/012.htm.

[17] Rosenberg M. J. (2001), E-Learning. Strategies for delivering knowledge in the digital age. New York, McGraw-Hill.

[18] Anderson, T., \& Elloumi, F. (2004). Theory and Practice of Online Learning. URL=http://www.cde.athabascau.ca/online_book. Athabasca University

[19] Mercado, C. (2008), "Readiness Assessment Tool for an E-Learning Environment Implementation". Special Issue of the International Journal of the Computer, the Internet and Management, Vol.16 No. SP3,

[20] Kaur, K. \&Abas, Z. (2004). An assessment of e-learning readiness at the Open University Malaysia. Proceeding of internationalconference on computers in education. (ICCE2004), Melbourne, Australia.

[21] Psycharis S. (2005). "Presumptions and actions affecting an e-learning adoption by the educational system - Implementation using virtual private networks".European Journal of Open, Distance and Elearning. URL= http://www.eurodl.org/materials/contrib/2005/Sarantos_Psycharis.htm.

[22] Rogers, E. M. (2003). Diffusion of innovations (5th Ed.), New York, NY.

\section{Author}

She is a faculty of the College of Computer Science of the Ifugao University, Nayon, Lamut, Ifugao, Philippines. Currently, she is undertaking a post-graduate in IT (DIT) at the University of the Cordilleras, Baguio City, Philippines. Her research interests are elearning and computer networks.

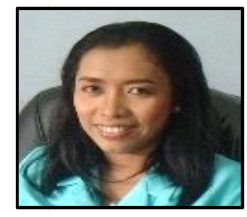

